\title{
Baselines, trajectories, and scenarios: Exploning agricultural production in the Northeast U.S.
}

\author{
Timothy Griffin a * \\ Tufts University \\ Christian Peters a \\ Tufts University \\ D avid Fleisher ${ }^{b}$ \\ U.S. D epartment of Agriculture \\ Agricultural Research Service \\ Michael Conard c
Columbia University
}

Zach Conrad a

Tufts University

\author{
Nicole Tichenor ${ }^{a}$ \\ Tufts University \\ Ashley McCarthy a \\ Tufts University \\ Emily Piltch a \\ Tufts University
}

Jonathan Resop b, d

U.S. D epartment of Agriculture

Agricultural Research Service

Houman Saberi c
Columbia University

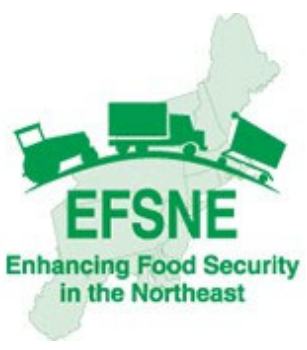

Enhancing Food Security

in the Northeast

Submitted August 14, 2017/ Revised February 7 and March 24, 2018 / Accepted April 6, 2018 /

Published online June 28, 2018

Citation: Griffin, T., Peters, C., Fleisher, D., Conard, M., Conrad, Z., Tichenor, N., McCarthy, A., Piltch, E., Resop, J., \& Saberi, H. (2018). Baselines, trajectories, and scenarios: Exploring agricultural production in the Northeast U.S.. Journal of A griculture, F ood Systems, and Community D evelopment, 8(2), 23-37. https:/ / doi.org/ 10.5304/ jafscd.2018.082.015

Copyright (c) 2018 by the Authors. Published by the Lyson Center for Civic Agriculture and Food Systems. Open access under CC-BY license.

\begin{abstract}
Agricultural production on farms and ranches in the U.S. contributes to the food supply and the food system on local, regional, national, and global

\footnotetext{
a Friedman School of Nutrition Science and Policy, Tufts University; 150 Harrison Avenue; Boston MA 02111 USA; christian.peters@ tufts.edu; zachconrad101@ gmail.com; ashley.mccarthy@ tufts.edu; emily.piltch@ tufts.edu; Nicole.tichenor@ tufts.edu

b U.S. D epartment of Agriculture Agricultural Research Service- Northeast Area, Adaptive Cropping Systems Laboratory; 10300 Baltimore Avenue; Beltsville, MD 20750 USA; david.fleisher@ARS.USA.gov

c Urban Design Lab at the Earth Institute, Columbia University; 475 Riverside D rive, Suite 239V; New York, NY 10115 USA; jmc52@ columbia.edu
}

scales. Increasing production at the regional scale- the focus of this research-depends on accurately estimating current production and understanding the mechanisms and resource

d Jonathan Resop is now at the Department of G eographical Sciences, University of Maryland; LeFrak Hall, 7251 Preinkert D rive; College Park, MD 20742 USA; resop@ umd.edu

* Corresponding author: Timothy G riffin, Friedman School of Nutrition Science and Policy, Tufts University; 150 Harrison Avenue; Boston MA 02111 USA; +1-617-636-3613; timothy.griffin@ tufts.edu

\section{Funding Disclosure}

This research was supported by the U.S. D epartment of Agriculture National Institute of Food and Agriculture (USD A NIFA) Agriculture and Food Research Initiative (AFRI) grant \#2011-68004-30057: Enhancing Food Security in the Northeast through Regional Foods Systems (EFSNE). 
requirements of production shifts. The Production Team of the EFSNE Project undertook seven studies that focused on current and potential production in the U.S. Northeast region, which includes nearly one-quarter of the population but only about $3 \%$ of national cropland. Here we summarize the results from these studies that: (1) estimate the regional self-reliance of primary crop, livestock products, and livestock feeds; (2) develop and implement a method to delineate urban, peri-urban, and rural zones around cities and analyze the distribution of food chain businesses across these zones; (3) assess crop yield trajectories to refine potential production increases associated with agricultural expansion into different land categories; and (4) model climate change and dietary impacts on yields and land use. The regional self-reliance of food crops varies widely, and the predominant agricultural use of land is for the production of animal feeds. The peri-urban zones contain significant agricultural production and concentrations of supply chain businesses. The potential to expand regional output via yield increases varies by crop and by land category and is strongly influenced by climate change. The diverse disciplines represented on the Production Team, along with significant leadership from graduate students and post-doctoral researchers, contributed to the broad array of studies completed.

\section{Keywords}

Regional Self-Reliance, Agricultural Productivity, Regional Food Systems, Climate Change, PeriUrban Agriculture

\section{Introduction and Literature Review}

Following the growth in agricultural output via land expansion in the U.S. prior to 1900, the most notable trends in the agricultural sector have been productivity increases, geographic concentration, and specialization at the farm level. These trends are apparent in both the crop and livestock sectors. The development of efficient transportation networks in the U.S. has led to the relocation (although not elimination) of earlier production centers that relied on perishable crop and livestock products produced near concentrated urban mar- kets. This shift in production centers has been very apparent in the Northeast U.S. For example, the agricultural land base has contracted by nearly $70 \%$ for a number of Northeast states, mostly after 1900 (G riffin, Conrad, Peters, Ridberg, \& Perry, 2015)

A number of notable trends in the agriculture and foods sectors contribute to a renewed interest in regional food production, including production in the Northeast U.S. First, there is increased risk associated with geographic concentration of production centers for both crops and livestock. These risks could plausibly be due to either biotic (e.g., pest outbreaks) or abiotic (e.g., drought or flooding) stressors, all of which increase under most climate change scenarios (Foley et al., 2011; Wolfe, Ziska, Petzoldt, Seaman, Chase, \& Hayhoe, 2008). Lengnick (2015) outlines the principle risks to different crop and livestock systems across the U.S., arguing for the need to increase resilience. Ruhf (2015) provides details on how regionalism can result in increased food system resilience. Second, increases in energy costs (such as those in 2007 to 2009) call into question the viability of longdistance transport without concomitant increases in food costs, an example of the relationship between input price shocks and food price increases (Tadasse, Algieri, Kalkuhl, \& von Braun, 2016). Third, in a more qualitative than quantitative trend, there has been a growing research base that examines the potential for regions to become more self-reliant in food provision, which can have positive impacts on food security, economic development, and ecological systems (Ruhf, 2015).

While similar in intent, research on regional food systems varies in scale. There are assessments of self-reliance potential that range from concentric spatial zones around cities such as San Francisco, California (Thompson, Harper, \& Kraus, 2008) and Philadelphia, Pennsylvania (D elaware Valley Regional Planning Commission, 2010); individual states (Peters, Wilkins, \& Fick, 2007); and multistate regions ( $\mathrm{G}$ riffin et al., 2015). In addition, some of these estimates are of arrent self-reliance (Conrad, Tichenor, Peters, \& G riffin, 2017) while others are of prospective self-reliance, that is, they assess potential changes in output under different scenarios. For example, Peters, Picardy, D arrouzetNardi, Wilkins, Griffin, and Fick (2016) evaluated 
land use and carrying capacity under a range of dietary scenarios.

The research project entitled Enhancing Food Security in the Northeast through Sustainable Regional Food Systems Development (hereafter, EFSNE) was initiated in 2010 with funding from the U.S. D epartment of Agriculture's (USD A) Agriculture and Food Research Initiative (AFRI). As noted in the special issue focusing on EFSNE research outcomes (Peters, Clancy, Hinrichs, \& G oetz, 2017), one of the research teams contributing to EFSNE focused specifically on agricultural production (and is thus referred to as the Production Team, represented by the authors of this paper). The Production Team undertook a number of research studies to assess current and future agricultural output for the Northeast region, and here we summarize the results of this multi-year interdisciplinary research effort.

\section{Focal Areas of Research by the Production Team}

The research of the Production Team focused specifically on the Northeast region of the U.S., inclusive of (approximately north to south): Maine, New Hampshire, Vermont, Massachusetts, Rhode Island, Connecticut, New Y ork, New Jersey, Pennsylvania, Maryland, D elaware, West Virginia, and the District of Columbia. There are seven studies described below, falling into three categories, which we call Baselines, Trajectories, and Scenarios.

Baselines: Potential changes in production are most meaningful in the context of the current system. The research in this section uses data from the recent past (post-2000) to establish benchmarks or baselines for agricultural production and the distribution of food system businesses. Specifically:

1. Estimation of regional self-reliance (RSR) for crop and livestock products consumed as food by people living in the region; we called this $\mathrm{RSR}_{\mathrm{FOOD}}$, and it is essentially the net balance between current consumption and production in the region;

2. Estimation of RSR for feed consumed by livestock raised in the region $\left(\mathrm{RSR}_{\mathrm{FEED}}\right)$; and

3. D elineation of zones within the urban/ peri-urban/ rural continuum and characterization of supply chain business locations along this continuum.

Trajectories: There are a myriad of data sources that can be used to refine productivity estimates in scenario analyses, and these estimates inform how yields or output may change in the future. We undertook two analyses, and the output from these served as input to other components of the EFSNE project. Specifically:

4. Calculation of yield trajectories (linear coefficients) for a subset of crops grown in the region using annual data from the period 1980-2013; and

5. Development of a crop productivity index to estimate additional crop output as different land categories are brought into production.

Scenarios: Just as the Baselines (above) are important to establish current conditions, modeling offers the opportunity to assess potential futures or scenarios, at a resolution ranging from $98 \mathrm{ft}$ by 98 $\mathrm{ft}(30 \mathrm{~m}$ by $30 \mathrm{~m})$ to the entire region. We utilized this range of options to:

6. Assess the impact of climate change on crop productivity using robust processbased crop simulations models (CSM). These models are available for only a small set of crops; we used CSM for maize, potato, and wheat (as representative of warm-season grain, cool-season grain, and vegetable crops, respectively); and

7. Q uantify the carrying capacity of the Northeast region under different diet scenarios, using the Foodprint model of Peters et al. (2007) and Peters et al. (2016).

\section{Research Methods and Results for the Seven Studies}

Study 1. Baseline: RSR for Food (RSR Food $_{\text {) }}$ A critical initial phase of the Production Team research was to establish the baseline for current agricultural production in the region. Because the 
EFSNE project also included a component on consumer access to healthy food, we wanted to estimate not only how much raw agricultural commodity was produced by farms in the region, but also to compare that production with total food consumption in the region. As stated in $\mathrm{G}$ riffin et al. (2015), the objectives of the research were to:

1. "D etermine how agricultural land is used in the Northeast region;

2. Determine the variety and amount of foods produced; and

3. Analyze the relationship between food consumption and agricultural output."

We developed a time-series dataset for 2001 to 2010 for land area, crop yield, crop output (land area $\mathrm{X}$ yield), and livestock inventory and output. G riffin et al. (2015) described the data development in detail, so we only summarize the approach here. The preferred data sources were the annual National Agricultural Statistics Service (NASS) surveys from the USD A, followed by the USD A NASS Agricultural Censuses (2002 and 2007). These two types of sources provided high-quality data on land area for many crops and agricultural land uses in the region, although less so for fruits, vegetables, and nuts. Estimates of yield from USD A were complimented by data from various state departments of agriculture and Cooperative Extension experts. D ata on livestock were developed using USD A-NASS slaughter reports and (in some cases) animal inventory or sales data, and also animal productivity data from USD A Economic Research Service (ERS) sources. Where feasible, data were aggregated first to the state level, and then to the entire region. Per-capita food

\footnotetext{
${ }^{1}$ D efined by USD A-NASS (2017, p. 17) as “agricultural land used for crops, pasture, or grazing. Also included is woodland and wasteland not actually under cultivation or used for
}

Figure 1. Proportional Use of Land for Crop Production in the Northeast U.S., Relative to Land in Farms (Total Land in Farms $=11.0$ million ha)

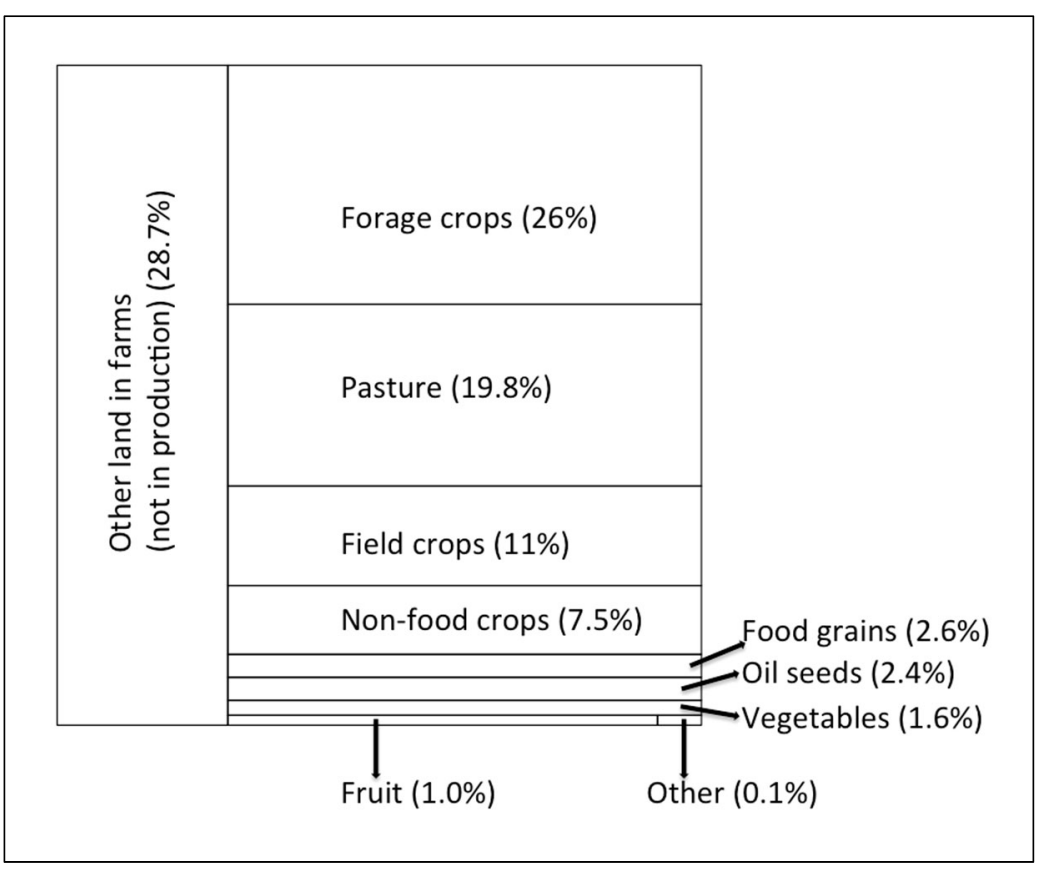

availability data (from the USD A ERS Food Availability D ata System) were used as a proxy for consumption.

The distribution of land uses on farms in the Northeast is summarized in Figure 1. More than a quarter $(28.7 \%)$ of the Land in Farms ${ }^{1}$ was not in production; this included a significant land area devoted to small woodlots on farms. More than one half (56\%) of the Land in Farms supported the livestock sectors in the region. The predominant land use of perennial forage crops and pasture support dairy and beef production. The remaining land area, about $13 \%$, is used to produce both food and nonfood crops (the latter encompasses nurseries and ornamental crops, including significant land area in Christmas tree production).

Relative to its population (approx. 23\% of the U.S.), the Northeast contains a small portion of Land in Farms (3.9\%); this is essentially the land base utilized by operations that meet the USD A definition of a farm. The region contains just 3\%

pasture or grazing, provided it was part of the farm operator's total operation. Land in farms includes acres in CRP, WRP, and other government conservation programs." 
Table 1. Mean Production and Consumption of Plant-based Foods in the Northeast Region (2001-2009)

\begin{tabular}{|c|c|c|c|}
\hline Self-reliance category & $\begin{array}{c}\text { Mean regional } \\
\text { production } \\
\left(10^{6} \mathrm{~kg}\right)\end{array}$ & $\begin{array}{c}\text { Mean regional } \\
\text { consumption } \\
\left(10^{6} \mathrm{~kg}\right) \\
\end{array}$ & $\begin{array}{c}\text { Mean } \\
\text { regional self- } \\
\text { reliance }(\%)^{a}\end{array}$ \\
\hline Fruit & 1389 & 7622 & 18 \\
\hline Commonly Eaten Fruitb & 1124 & 6590 & 17 \\
\hline Berries & 167 & 278 & 60 \\
\hline Melons & 98 & 754 & 13 \\
\hline Vegetables & 2953 & 11,387 & 26 \\
\hline Dark Green Vegetables & 39 & 364 & 11 \\
\hline Starchy Vegetables & 1458 & 4472 & 33 \\
\hline Red and Orange Vegetables & 452 & 3554 & 13 \\
\hline Other Vegetables & 1003 & 2996 & 33 \\
\hline Food grains & 1150 & 14,627 & 7.9 \\
\hline Pulsesc & 15 & 212 & 7.2 \\
\hline Oils d & 1396 & 14,398 & 9.7 \\
\hline Sweetenerse & 290 & 3752 & 7.7 \\
\hline Total & 11,535 & 71,005 & 16 \\
\hline
\end{tabular}

a Percent of regional consumption met by regional production, (Production/Consumption)* 100

${ }^{b}$ All fruit except berries and melons

$c$ Dry beans and peas

dCorn, soybean, canola

e High-fructose corn syrup, glucose, honey, cane and beet sugar, maple syrup, molasses, refiners' syrup, surgarcane syrup, sorgo

of the cropland in the U.S. Additionally, as shown in Table 1 , the RSR FOOD $_{\text {is }}$ at or above $23 \%$ for only a limited number of food categories. Some may be tempted to adopt the value $23 \%$ (i.e., the regional proportion of the national population) as a reference point to compare $\mathrm{RSR}_{\mathrm{FOOD}}$ against, and doing so implies that the region is over-reliant on food from outside the region. Yet, importantly, we posit that there is no evidence for assigning any particular value as the optimal RSR FOoD $_{\text {, and we }}$ recommend that different reference points be used for interpretation depending on the study question.

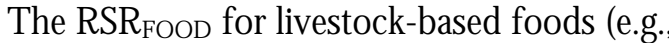
meat, dairy, and eggs) ranges from $15 \%$ to $76 \%$, for pork and dairy products (fluid milk equivalent), respectively (see Table 3 in G riffin et al., 2015, for details). The high $\mathrm{RSR}_{\mathrm{FOOD}}$ for dairy reflects not only the large land base used for this subsector, but also the perishability of fluid milk; the region is essentially self-reliant for fluid milk, which is generally transported less than several hundred miles from production.
Study 2. Baseline: RSR for F ood (RSRFE E D)

Given the importance of land used to support livestock production in the region, shown in Figure 1, we sought to assess the degree to which the region meets its own feed needs for the primary livestock categories. This is directly analogous to the RSR for food (i.e., $\mathrm{RSR}_{\mathrm{FOOD}}$ ) described above, and the supply side of the estimation is largely contained in G riffin et al. (2015). Conrad et al. (2017) extended this approach by estimating regional livestock feed demand for major livestock categories (beef, dairy, swine, poultry including eggs) using the model of Peters, Picardy, D arrouzetNardi, and Griffin (2014). This model uses maize and soy as the primary feed components to supply energy and protein, respectively, for all livestock categories. Forage requirements in dairy rations are met with com silage, alfalfa, and mixed forages (as hay or haylage), but no pasture. As shown in Figure 2 (from Conrad et al., 2017), about $60 \%$ of total demand for protein and energy (as total digestible nutrients, TD N) is from the dairy sector, followed by broiler chicken production.

The production of both grain crops (concentrates) and harvested forage, along with pasture use, is concentrated in a few states in the region (see Table 1 in Conrad et al., 2017, for livestock-associated land use for the entire recion): New Y ork, Pennsvlvania, and West Vircinia contain more than $80 \%$ of the region's forage and pasture land, while New York, Pennsylvania, and Maryland contain more than $90 \%$ of the region's cropland used for grain feeds. The land base used for pasture in the region is more than 2 million hectares (nearly 5 million acres), but is primarily 
used at low intensity for beef production.

Using data on livestock product output and feed production, we estimated RSR $\mathrm{FEED}_{\mathrm{F}}$ based on both energy and protein (TD N and CP, respectively), as shown in Figure 3. This shows that the region is almost 93\% selfreliant for energy, and about $68 \%$ self-reliant for protein. It is assumed that most of the feed entering the region is, in fact, concentrates like corn and soy, as the transportation cost of forage crops is typically not justifiable because of low energy density, high moisture content (for silages), or both.

Study 3. Baseline: The U rban/ Peri-U rban/ Rural Continuum Agricultural production in the Northeast region, as in other regions, obviously occurs in rural areas-but not exclusively so. The visibility and potential of urban agriculture to both provide educational and cultural opportunities and to contribute to increased food security is also notable. The more ambiguous zone is the peri-urban zone, which contains a mixture of lower-density residential areas, industry, and farms. Although there is much anecdotal evidence that these peri-urban zones around cities have historically been an important source of food, assessing the current role depends on the ability to delineate the peri-urban area from the urban core and from the outlying agricultural zone. To date, there has not been a codified protocol for this delineation. The Urban D esign Lab (Columbia University), as part of the Production Team, led the study described here to develop and implement a data-driven approach that delineates urban, peri-urban, and rural zones around the urban centers in the EFSNE project, and
Figure 2. Proportional Demand for Crude Protein (CP) and Total Digestible Nutrients (TDN) by Livestock Category in the Northeast U.S.

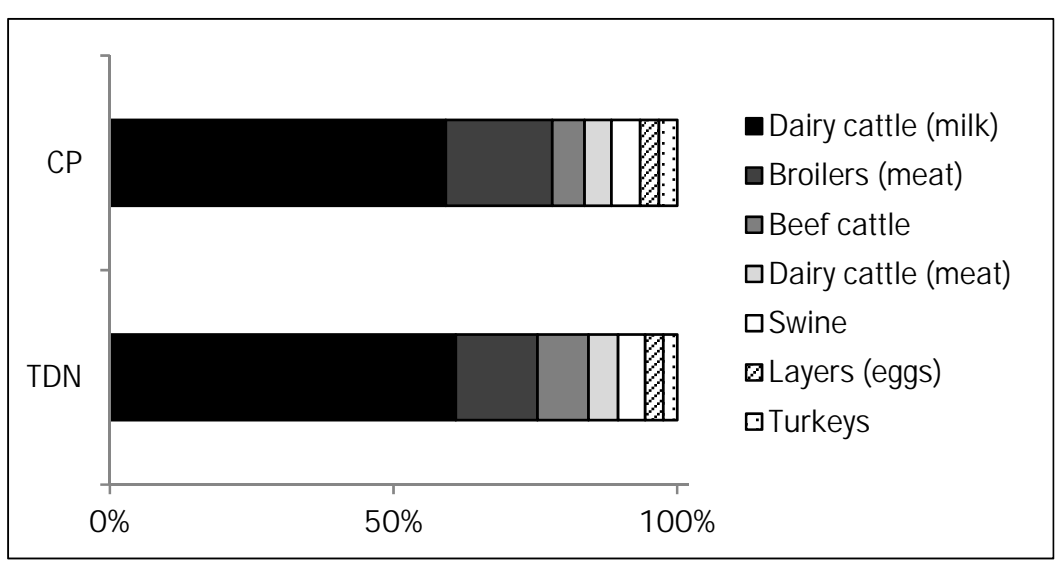

Source: Adapted from Conrad, Tichenor, Peters, \& Griffin (2017). subsequently to assess the distribution of food zones.

The delineation of zones proceeded in three phases, each of which provided data layers within a geographic information system (GIS). First, the study areas were defined as the cities that served as EFSNE research sites--i.e., Baltimore, Maryland; Charleston, West Virginia; New York City, New York; Philadelphia, Pennsylvania; Pittsburgh, Pennsylvania; and Syracuse, New York. Surrounding counties (43 in total) were included in the study

Figure 3. Regional Self-reliance for Energy and Protein Demand by Livestock in the Northeast U.S.

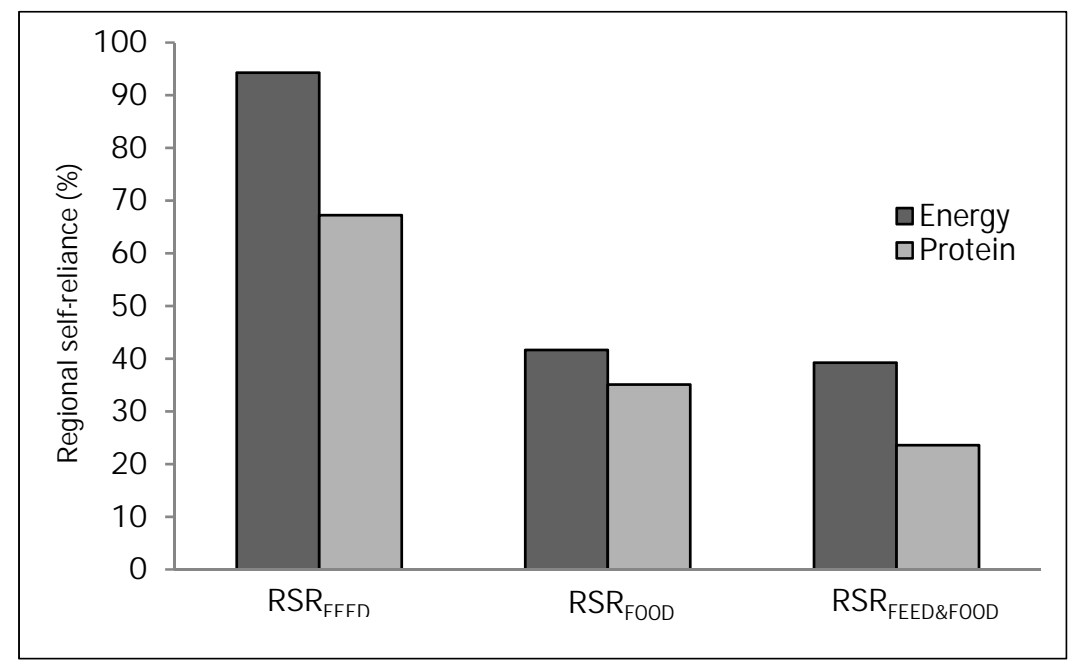

Source: Adapted from Conrad, Tichenor, Peters, \& Griffin (2017). 
Figure 4. Rural/ Agricultural Zone (Green) Surrounding Syracuse, NY, Urban Core (Black); Delineated Peri-Urban Area Is In Gray

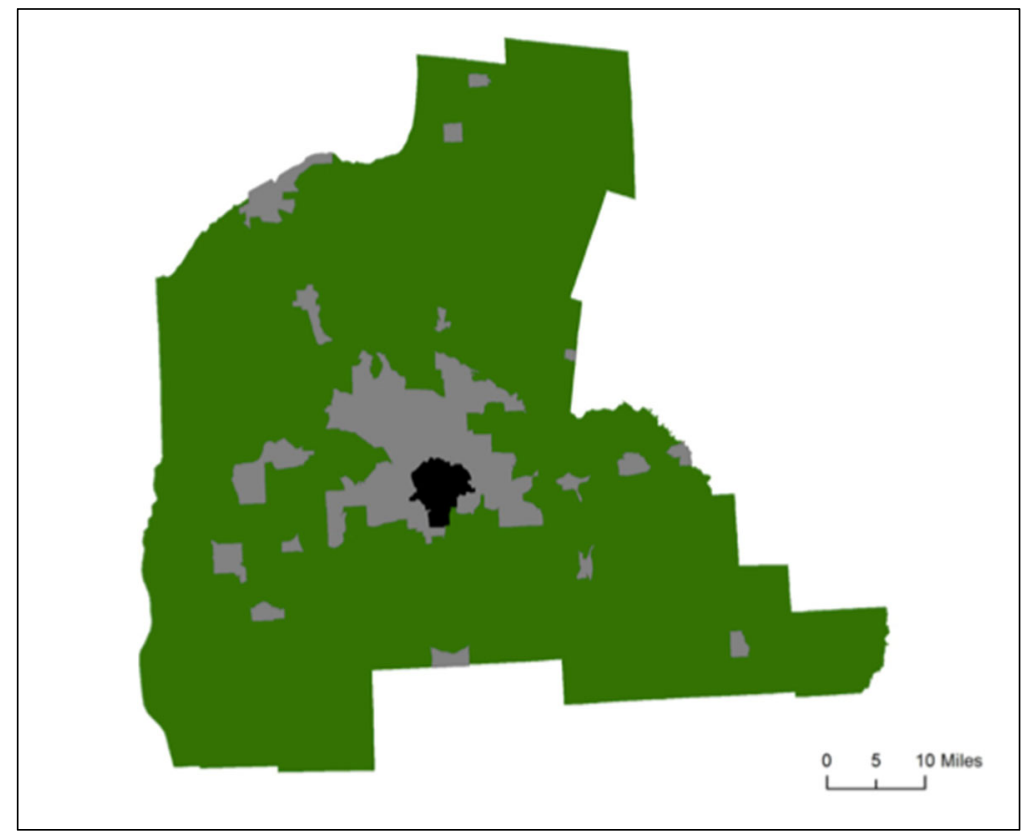

(2010 U.S. Census), and zoning boundaries. Because detailed zoning boundaries only existed for the Baltimore study area, a novel machine learning approach was developed specifically to identify the rural zone of the continuum using the National Land Cover D atabase. At the resolution of census blocks, an algorithm was trained to recognize land-cover characteristics that are rural or agricultural or both. This algorithm was then applied to the other five study areas in the region. To illustrate the output from these phases, the resulting delineation of the urban (defined by a metropolitan boundary), periurban, and rural zones of Syracuse and the surrounding area is shown in Figure 4.

The third phase was to establish a

areas (using data on commuting distances) to ensure that the continuum was represented. The second phase was to define and delineate the periurban area. This used a combination of RuralUrban Community Area (RUCA) codes (USD AEconomic Research Service), population density

Figure 5: Urban, Peri-urban, and Rural Zones of Baltimore, Maryland, and Surrounding Area

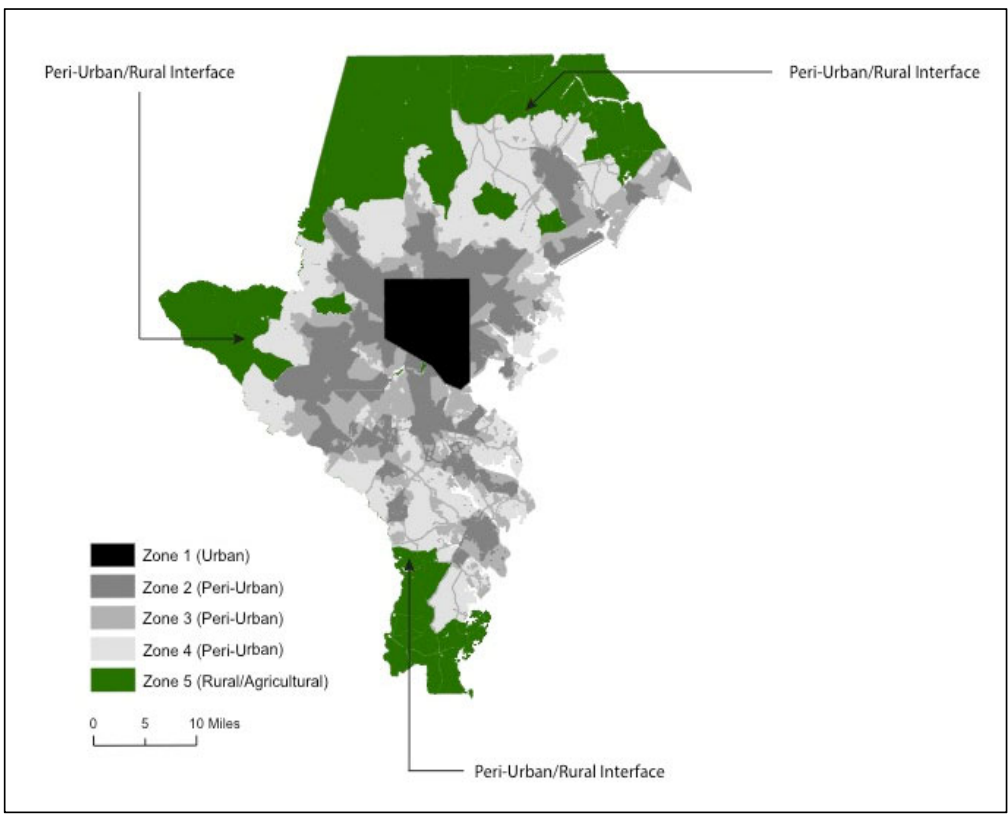
finer gradation or zonation through the peri-urban area, using overlapping map layers for commuting, density, and zoning. The urban core was designated as Zone 1, and the rural/ agricultural area was designated as Zone 5; Zones 2, 3 and 4 (moving out from the urban center) are all within the peri-

urban zone. These zones were identified as follows:

Zone 2: All three boundaries (commuting, density, and zoning) overlap: heavy pressure.

Zone 3: Two of the three boundaries overlap: medium pressure.

Zone 4: O ne boundary only: low pressure.

The delineated urban, peri-urban, and rural continuum for Baltimore, Maryland, and the surrounding area is shown in Figure 5. The protocol described above was eventually scaled to the entire Northeast region.

The second objective (above) was to assess the current distribution of 
food supply chain businesses across the resulting zones by using business data from the U.S.

Census's North American Industry Classification System (NAICS). Included in these data is the location of businesses engaged in agricultural production, storage, processing, wholesale, and retail. This was included as a data layer in the GIS and allowed the number of businesses of each type within each zone (1-5) to be considered.

The peri-urban mapping study resulted in consistent and clearly defined urban, peri-urban, and rural zones, as shown above. Analyzing the distribution of agricultural businesses across these zones revealed the disproportional contribution of the peri-urban areas to existing food supply chains. Noting that the peri-urban areas compose about $22 \%$ of the land area in the Northeast, Figure 6 shows that, for the entire EFSNE region, one-half or more of each business type's expected production is located within peri-urban areas. Table 2 shows the share of each agricultural business type that is located within the combined peri-urban zones (Zones 2-4) within the six urban research sites. Across the six study cities in the EFSNE project, the peri-urban zones contained the largest
Figure 6. Distribution of Food Supply Chain Business Categories across Urban, Peri-urban, and Rural Zones for EFSNE Research Sites in the Northeast U.S.

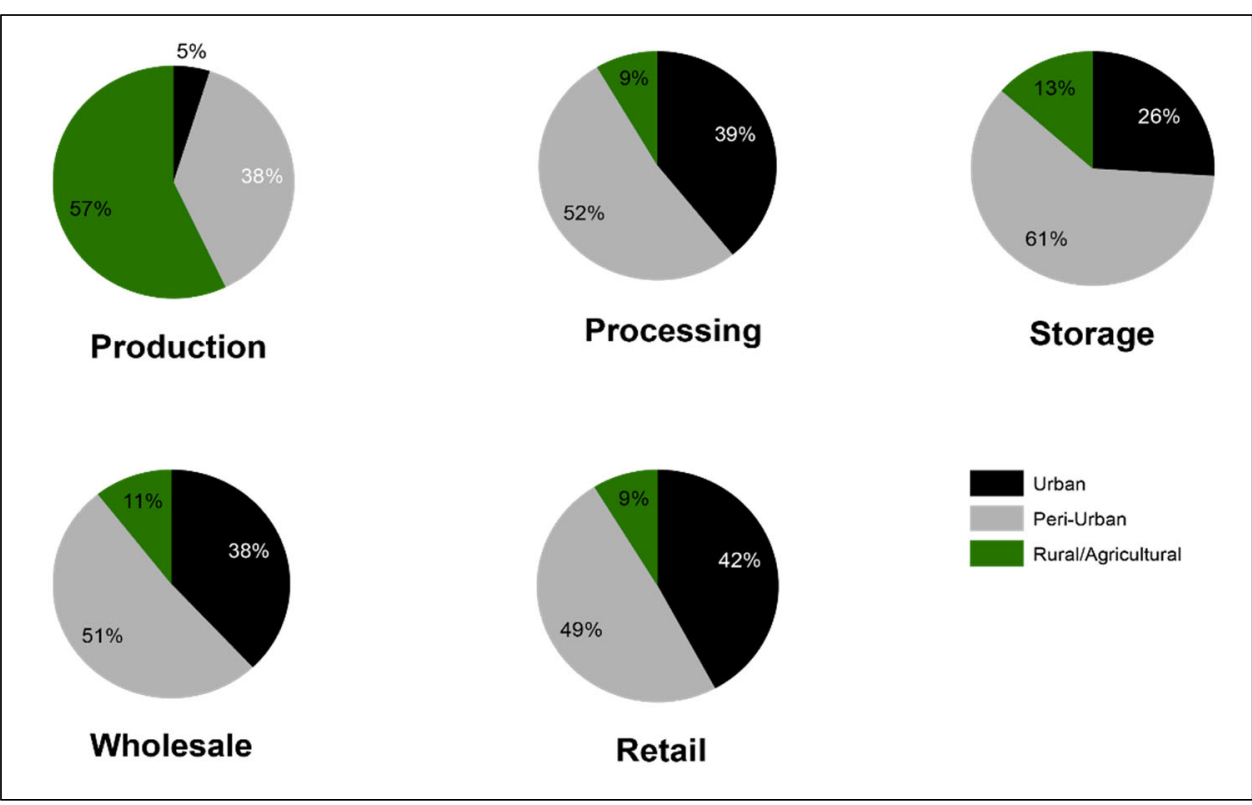

share of the production, processing, wholesale, retail, and storage business areas in a majority of instances. There are also distinct differences between EFSNE research sites in how business types are distributed across the zones. For some sites (Baltimore and Philadelphia, for example) one-half to three quarters or more of supply chain businesses are located in the peri-urban zones-and this includes production businesses such as farms. In comparison, Charleston, West Virginia, has only wholesale and retail businesses concentrated within its peri-urban zones.

\section{Study 4. T rajectory: Crop Y ields}

The expanded regional output of any particular crop can be realized only through a limited set of mechanisms, including increased crop yield,

Table 2. Proportion (\%) of Food Business Categories Located in the Peri-urban Zones (2-4) Surrounding EFSNE Urban Research Sites in the Northeast U.S.

\begin{tabular}{lcccccc}
\hline & Baltimore & Charleston & New York City & Philadelphia & Pittsburgh & Syracuse \\
\hline Production & 51 & 0 & 91 & 81 & 40 & 6 \\
Processing & 61 & 35 & 44 & 68 & 71 & 51 \\
Wholesale & 64 & 58 & 48 & 67 & 73 & 39 \\
Retail & 56 & 56 & 41 & 56 & 71 & 36 \\
Storage & 75 & 0 & 79 & 84 & 0 & 100 \\
\hline
\end{tabular}


Figure 7. Changes in Wheat Yield in the Northeast U.S., 1980-2010

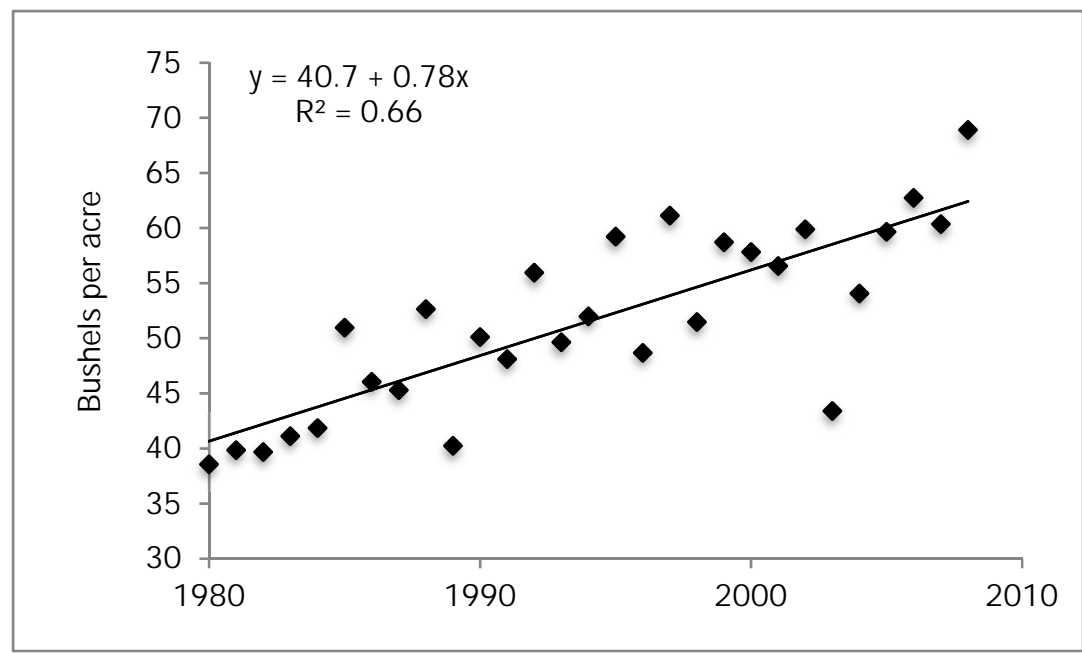

respectively, as in [1]. This provides an estimate of annual yield gain relative to the yield in 1980 . This measurement is often misinterpreted as annual gain, which would result in an exponential trajectory. The relative yield gain varies widely, from $-0.20 \%$ to $2.31 \%$, for alfalfa hay yield and milk production, respectively, as shown in Table 3. These coefficients can be used to estimate intervals or ranges for future productivity gains.

Study 5. T rajectory: D evelopment of a Productivity Index

O ne strategy to increase food production within the region is to bring new land into agriculture. For example, current land in forest could be converted to agricultural production. It is important to consider the differences in productivity across the landscape in order to understand how the region's capacity for food production would change if more land were brought into agriculture. We initiated the development of a productivity index to estimate the potential productivity of an expanded agricultural land base. The productivity index uses geospatial data to quantify the relationship between a specific type of land cover and its potential productivity for different crops. When combined with the amount of land in each type of land cover, the productivity index can be used to estimate the productive potential for each type of land cover and for the region as a whole.

Table 3. Relative Yield Gain for Selected Crops and Milk Production in the Northeast U.S., 1980-2010

\begin{tabular}{lc}
\hline Product & Relative Annual Yield Gain (\%) \\
\hline Alfalfa Hay & -0.20 \\
Corn -Grain & 1.72 \\
Corn -Silage & 1.15 \\
Milk & 2.31 \\
Potato & 0.91 \\
Soybean & 1.64 \\
Wheat & 1.91 \\
\hline
\end{tabular}


To develop the index, we used the 2014 Cropland D ata Layer (CDL) to assign all land in the region to one of eight land cover types: vegetables, melons, and potatoes; berries, grapes, and tree crops; other cultivated crops and alfalfa; non-alfalfa hay and pasture; fallow and idle cropland; shrub and scrubland; forest; and all other land. We used the G ridded Soil Survey G eographic (gSSURGO) database to identify arable land in the region based on land capability classification, and also to obtain National Commodity Crop Productivity Index (NCCPI) values for each unit of land. We then used the NCCPI as a proxy for productivity in the analysis. Using these data and spatial analysis tools, we estimated basic descriptive statistics for the NCCPI values for arable land within each type of land cover; we then quantified the amount of arable land area within each type of land cover. We used these results from the spatial analysis to generate a production function that relates the area of land to product output in the Northeast. The results of this analysis allow us to better understand the relationship between land cover type and productivity as well as the aggregate potential production capacity of the region. The initial results from the analysis demonstrate declining returns to land as more land is brought into agriculture because of a decrease in productivity for each additional unit of land; an example (for New York state) is shown in Figure 8. The production functions generated provide a way to mathematically show this relationship and establish the land cost of bringing less productive land into production. The outcomes of this project will feed into the broader work of the Production and Distribution teams.

Study 6. Sœnario: M odeling for Ex pansion and Climate $C$ hange Impacts

Growing conditions vary widely across the Northeast region, encompassing a wide range of soils and climatic conditions. D ifferent scenarios can be evaluated using crop simulation models (CSM) for a specific subset of crops--i.e., those for which robust, validated models are available. The Production Team used CSM for three crops (maize, wheat, and potato) to address questions about potential expansion of land area used for each crop, and also to assess production potential under climate change. Some of the results for potato are used here to illustrate our work.

Resop, Fleisher, Timlin, \& Reddy (2014) used the well-established potato CSM, SPUD SIM

Figure 8. Production Function for Expanded Agricultural Land Base in New York

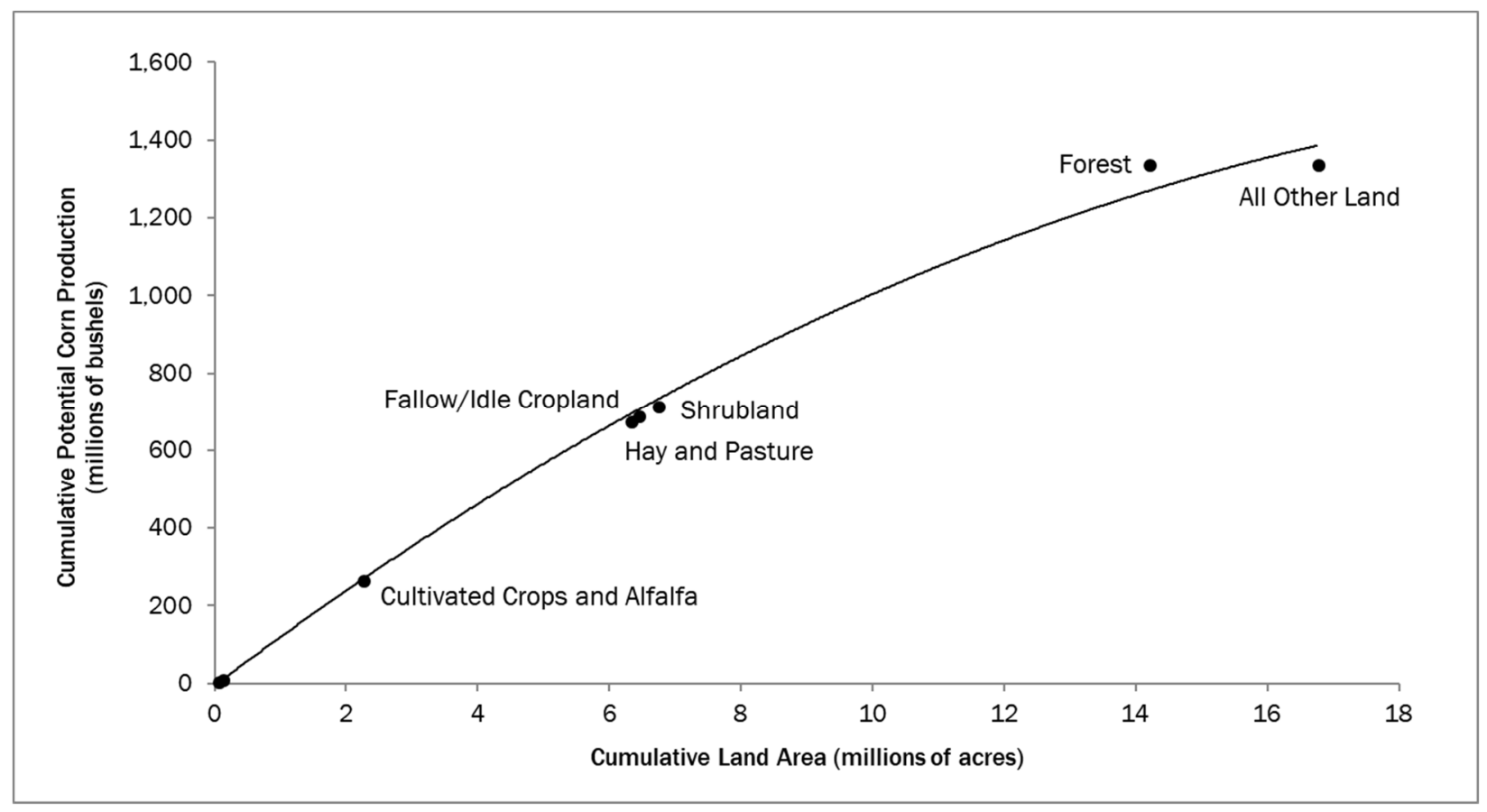


(Fleisher, D athe, Timlin, \& Reddy, 2015; Fleisher, Timlin, Yang, \& Reddy, 2010), to quantify the impact of soil, climate, and management (irrigation and nitrogen, specifically) on agronomic potato yield. D ata presented in Figure 9 confirm that climate factors have a significant impact on the potential yield of potato; there is a pronounced

Figure 9. Simulated Potato Yield under (a) Water-Limited and (b) Non-Limited Conditions in the Eastern U.S. under Historical Climatic Conditions

Results were spatially aggregated from 16 to $30 \mathrm{~m}$ resolution

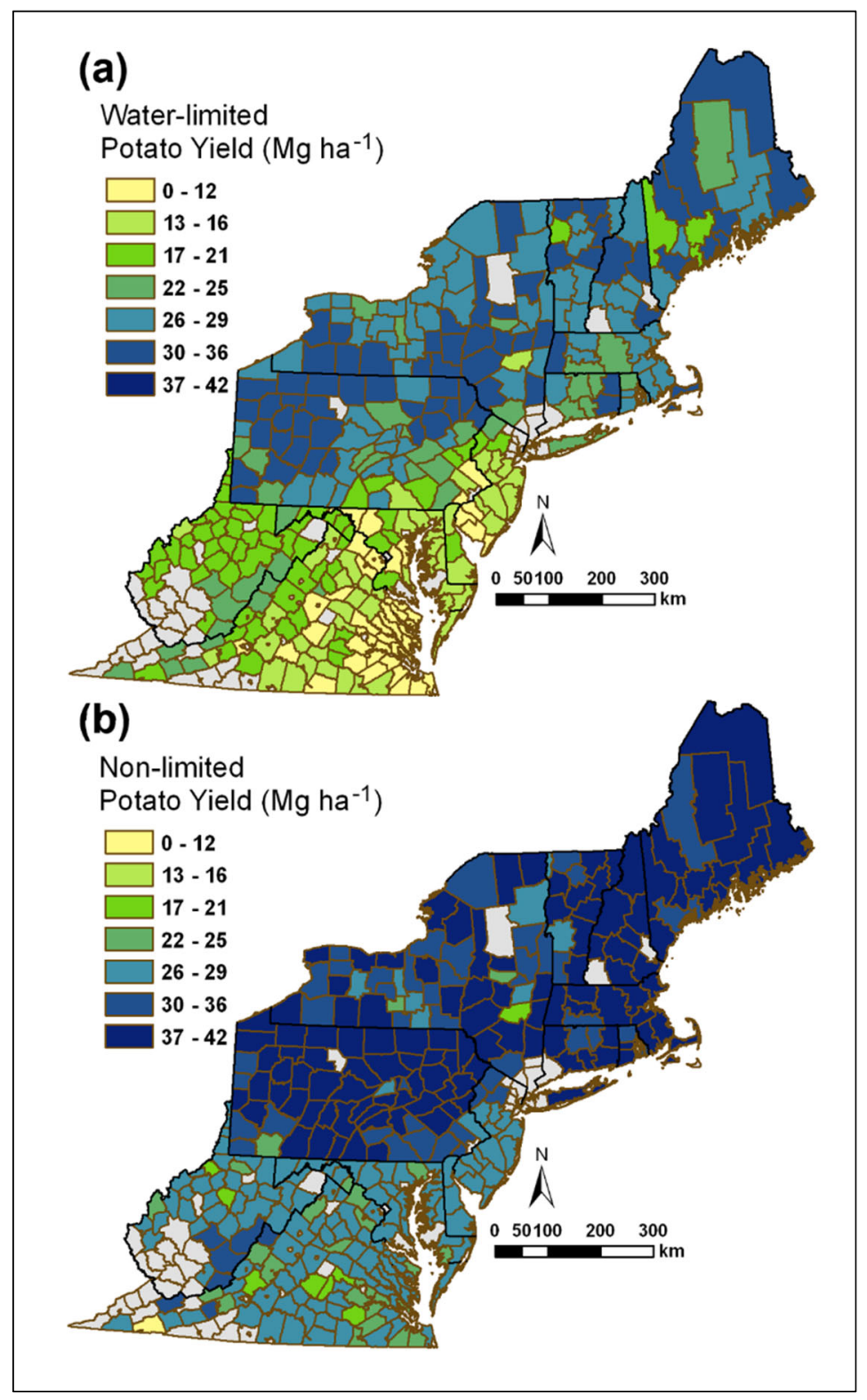

Source: Resop, Fleisher, Timlin, and Reddy 2014. north-south gradient for increased temperature in the region, and the higher temperatures in the southern part of the region depress yield. This can be ameliorated in part by looking at non-water limiting conditions (compare (a) and (b) in Figure 9) because the evaporative demand increases with temperature. The impact of soil properties was notably smaller than that of climatic factors.

Because potato is sensitive to high temperature and moisture stress, the implications of climate change are cause for concern. Resop, Fleisher, Mutiibwa, Timlin, and Reddy (2016) used SPUD SIM to simulate the impact of increased temperature and shifting precipitation patterns across the region. Climate change scenarios included temperature increases ranging from $3.6^{\circ} \mathrm{F}$ to $7.7^{\circ} \mathrm{F}\left(2.0^{\circ} \mathrm{C}\right.$ to $4.3^{\circ} \mathrm{C}$ ) and changes in annual precipitation ranging from $-5 \%$ to $16 \%$. They found that yields could be reduced by $50 \%$ to $80 \%$ if farmers did not implement adaptation strategies, which could be as simple as shifting planting dates. This decrease was simulated despite the fertility effect that has been associated with increased carbon dioxide concentration. In the southern part of the region, most of the yield reduction was due to water constraints, along with warmer temperatures. While implementing proven adaptation strategies or practices could reduce the predicted yield impact by half, the consequences would still be substantial. Climate impacts were less severe on maize production, with an average 19\% reduction in silage if no adaptation measures were implemented (Resop et al., 2016). In contrast, winter wheat showed a sharp increase in grain yield (by as much as 50\% above the current yield levels), depending on location in the region (data not published). This increase was primarily on account of warmer temperatures resulting in a more favorable growth environment. In general, the results suggest that the agricultural land base may need to be 
reconfigured by the selection of new crop commodities that are currently not grown in the area, or via an increase in production area for crops that are better adapted to warmer climates.

Study 7. Sœnario: Carrying Capacity of the $\mathrm{N}$ ortheast Region under D ifferent D iet Scenarios

Most of the research described above focuses on individual crops or livestock products. This last study from the Production Team focuses on the capacity of the regional land base to produce complete diets. This was accomplished by modifying the well-documented model from Peters et al. (2007) and Peters et al. (2016) to make it specific to the Northeast region. This spreadsheet-based model uses data on crop yield and animal productivity to estimate the land requirement of specific diets; availability of different foods is estimated using the Loss Adjusted Food Availability dataset from USD AERS. In this application, the 10 diets included the current U.S. diet, vegan, lacto-ovo-vegetarian, and six diets that varied in the preference for beef in the diet (i.e., they varied in how non-beef meats were allowed as substitutes for beef). The diets were isocaloric and met the 2010 Dietary Guidelines for Americans.

The land requirements of the various diets vary fourfold (Figure 10). Increasing consumption of beef forces more land to be used for perennial forage production and pasture. At high levels of preference for beef, some of this forage production is on land typically used for annual crop production. It is important to note that the land area devoted to annual crop production varies only slightly across the 10 diet scenarios. The carrying capacity can be estimated based on per-capita dietary demand and regional population; this estimation is related to (but distinct from) the land requirement estimation. As expected, the carrying capacity varies significantly across the diets evaluated (Table 4), but over a smaller range than land requirement. The principle reason for the difference is that there is a substantial land base in the region that is suitable only for perennial forage production (i.e., annual crops would not be suitable for this land base).

\section{Discussion}

An appraisal of agricultural production at the regional scale should encompass four components. First, as noted by Ruhf and Clancy (2010), it should

Table 4. Carrying Capacity of the Northeast Region as a Function of Diet

\begin{tabular}{lcc}
\hline Diet pattern & $\begin{array}{c}\text { People fed } \\
\text { (n x 103) }\end{array}$ & $\begin{array}{c}\text { Population fed } \\
\text { (\%) }\end{array}$ \\
\hline Current & 10,864 & 17 \\
\hline Vegan & 15,087 & 23 \\
\hline Lacto-ovo-vegetarian & 18,001 & 28 \\
\hline No beef preference & 12,651 & 20 \\
\hline Beef preference 0\% & 12,219 & 19 \\
\hline Beef preference $25 \%$ & 12,631 & 20 \\
\hline Beef preference $50 \%$ & 13,057 & 20 \\
\hline Beef preference $75 \%$ & 11,121 & 17 \\
\hline Beef preference $100 \%$ & 8,919 & 14 \\
\hline
\end{tabular}


recognize that the food system is composed of multiple overlapping and complementary scales. Within each of these scales (local, regional, national, and global), available resources can constrain agricultural production. Second, there is a finite set of mechanisms by which regional production can be increased. These include yield increases for crops and livestock (through efficiency gains, genetic improvement, and the like), crop substitution, and expansion of the land base. The first and last of these mechanisms are generally referred to as intensification and ex tensification, respectively. Third, it is important to recognize that the provision of agricultural products to consumers depends on the complex interactions between myriad supply chain businesses. And fourth, there are multiple drivers that either constrain the capacity to increase production or send direct market signals to farms and ranches to alter production. Principle among these drivers are climate change and dietary demand. The research portfolio of the Production Team intentionally tried to capture this range of objectives and associated methodologies.

The two studies that quantify the regional selfreliance (RSR) were referred to as "The Baseline" by the Production Team. These were the first studies to be undertaken by the team and literally established the baseline balance between production and consumption. The RSR presented here is generally aggregated to the level of food categories, although the data are at the resolution of individual crops and livestock. Spatially, the requisite data were at the levels of states in the northeast region. For a few crops (mostly commodity grains and oilseeds), the production data could be developed at the county level, while some livestock categories can only be documented at the level of multiple states (e.g., some animal slaughter data are compiled for the six New England states in aggregate). The results of these two studies are useful in identifying products or categories that have production centers in the region (for example, cabbage is one of the market basket products for EFSNE).

The northeast region has a high population density compared to other regions of the U.S., so much of the farm-level production occurs near cities. There was a clear need to develop a more nuanced picture of where farms and other businesses are located relative to those cities. Of particular interest were peri-urban areas, which anecdotally contain a mosaic of residential, industrial, and rural characteristics. The Production Team developed a protocol to delineate peri-urban zones that initially focused on Baltimore, Maryland, and the surrounding area, but was eventually applied to the other urban EFSNE research sites and then to the entire region. This is a necessary first step to take a more strategic approach to locating food supply chain businesses.

Changes in crop and livestock productivity are not likely to be uniform across the region, and further refinements are needed as we look to the future of the region's food system. As noted earlier, it is possible to expand aggregate production by increasing yield, expanding the land base used for production (recognizing the inherent differences in soil resources and other factors), or both simultaneously. O ur analysis of yield trends confirms that (1) the yields of a few commodity grain and oilseed crops, along with milk, have very pronounced positive trends, commensurate with the decades-long public and private investment in the productivity of these products, and (2) some of the crops that occupy the largest agricultural land areas in the region, such as grass, and alfalfa hay, have flat or even negative yields trends over this period. It also should be noted that data availability constrains this type of analysis for many food crops, including most fruits, vegetables, and nuts.

Future production can be simulated at different levels of spatial resolution and in response to different drivers. On the supply side, this includes inherent resource constraints like soil productivity and also the availability of resources and inputs like land, water, and nutrients. Using crop simulation models, the Production Team developed a series of questions around which simulations could be conducted. In general terms, these questions included:

1. What is the regional variability in crop yield (for corn, wheat, and potato specifically) that results from variation in soil productivity and climate?

2. How does productivity change as new land is brought into production? 
3. What is the magnitude of the impact of climate change on crop productivity?

Although validated crop simulation models are available for relatively few crops, those that we had access to and experience with represented warm season grain (corn), cool season grain (wheat), and cool season vegetable (potato). Much of this work was done at fine-scale resolution, on the order of $184 \mathrm{ft}$ by $184 \mathrm{ft}$ ( $56 \mathrm{~m}$ by $56 \mathrm{~m}$ ), and then aggregated upward to the scale of the region. Because of this high resolution, data development, curation, transfer, and processing, and analysis were notable challenges. We also linked demand and supply by quantifying regional carrying capacity as affected by dietary demand. This was important within the context of the EFSNE project, which includes consumption, supply chain, and production realms. It also highlights that demand is a primary driver of production; sustainability outcomes can only be achieved within the context of sustainable consumption (Moomaw, G riffin, K urczak, \& Lomax, 2013).
The coordinated research effort described here represents six years of research and contributions from more than 30 people, including faculty, postdoctoral associates, graduate students, and practitioners and community members; various aspects of this work are described elsewhere (for example, see Clancy et al., 2017; Palmer et al., 2017). Much of the coordination across the investigators was accomplished virtually; the Production Team held biweekly conference calls for more than four years. They also met in person at least once per year, in addition to the annual EFSNE project meeting. Notably, these annual team meetings relied on resources beyond those available from the EFSNE budget. In addition to our research focus, the Production Team actively provided opportunities for graduate students to take leadership roles, in some instances to act as a liaison between different EFSNE teams. All of the studies described here engaged graduate students, and several (e.g., RSR, peri-urban zonation, and productivity index) would not have been possible without student leadership and innovation.

\section{References}

Clancy, K., Bonanno, A., Canning, P., Cleary, R., Conrad, Z., Fleisher, D., Gómez, M., Griffin, T., Lee, R., Kane, D., Palmer, A., Park, K., Peters, C. J., \& Tichenor, N. (2017). Using a market basket to explore regional food systems. Journal of A grioulture, F ood Systems, and Community D evelopment, 7(4), 163-178. https:// doi.org/ 10.5304/jafscd.2017.074.018

Conrad, Z., Tichenor, N. E., Peters, C. J., \& G riffin, T. S. (2017). Regional self-reliance for livestock feed, meat, dairy and eggs in the Northeast USA. R enewable A griculture and Food Systems, 32(2),145-156. https:/ / doi.org/ 10.1017/ S1742170516000089

Deleware Valley Regional Planning Commission. (2010). G reater Philadelphia food systems study. Retrieved August 11, 2017, from http:// www.dvrpc.org/ food/ foodsystemstudy.htm

Fleisher, D . H., Timlin, D . J., Y ang, Y., \& Reddy, V. R. (2010). Simulation of potato gas exchange rates using SPUD SIM. A gricultural and Forest M eteorology, 150 (3), 432-442. https:// doi.org/ 10.1016/ j.agrformet.2010.01.005

Fleisher, D . H., D athe, A., Timlin, D. J., \& Reddy, V. R. (2015). Improving potato drought simulations: Assessing water stress factors using a coupled model. A griaultural and F orest M eteorology, 200, 144-155. https:/ / doi.org/ 10.1016/ j.agrformet.2014.09.018

Foley, J. A., Ramankutty, N., Brauman, K. A., Cassidy, E. S., Gerber, J. S., Johnston, M.,... Zaks, D. P. M. (2011). Solutions for a cultivated planet. $N$ ature, 478, 337-342. https:/ doi.org/ 10.1038/ nature10452

Griffin, T., Conrad, Z., Peters, C., Ridberg, R., \& Perry, E. T. (2015). The regional self- sufficiency of the Northeast food system. Renewable A griculture and F ood Systems, 30(4), 349-363. https:/ / doi.org/ 10.1017/ S1742170514000027

Lengnick, L. (2015). The vulnerability of the US food system to climate change. Journal of E nironmental Studies and Scienœ, 5(3), 348-361. https:// doi.org/ 10.1007/ s13412-015-0290-4

Moomaw, W., Griffin, T., Kurczak, K., \& Lomax, J. (2012). The critical role of global food consumption patterns in achieving sustainable food systems and food for all: A U N E P discussion paper. Paris: United Nations Environment Programme, Division of Technology, Industry and Economics. Retrieved from http:// www.thinkeatsave.org/docs/Role_of_Global_Food_Consumption_PatternsA UNEP_Discussion_Paper.pdf 
Palmer, A., Santo, R., Berlin, L., Bonanno, A., Clancy, K., Giesecke, C., Hinrichs, C. C., Lee, R., McNab, P., \& Rocker, S. (2017). Between global and local: Exploring regional food systems from the perspectives of four communities in the U.S. Northeast. Journal of A griculture, F ood Systems, and Community D evelopment, 7(4), 187-205. https:// doi.org/ 10.5304/ jafscd.2017.074.017

Peters, C. J., Picardy, J., D arrouzet-Nardi, A. F., Wilkins, J. L., G riffin, T. S., \& Fick, G. W. (2016). Carrying capacity of U.S. agricultural land: Ten diet scenarios. E lementa: Scienœe of the A nthropocene, 4, 116. http:// doi.org/ 10.12952/ joumal.elementa.000116

Peters, C. J., Picardy, J. A., D arrouzet-Nardi, A., \& G riffin, T. S. (2014). Feed conversions, ration compositions, and land use efficiencies of major livestock products in US agricultural systems. A grialtural Systems, 130, 35-43. https:// doi.org/ 10.1016/ j.agsy.2014.06.005

Peters, C. J., Wilkins, J. L., \& Fick, G. W. (2007). Testing a complete-diet model for estimating the land resource requirements of food consumption and agricultural carrying capacity: The New York State example. Renewable A griculture and Food Systems, 22(2), 145-153. https:/ / doi.org/ 10.1017/ S1742170507001767

Peters, C. J., Clancy, K., Hinrichs, C. C., \& G oetz, S. (2017). Introduction to the EFSNE project collection of papers. Journal of A griaulture, Food Systems, and Community D evelopment, 7(4), 159-162. https:// doi.org/ 10.5304/ jafscd.2017.074.019

Resop, J. P., Fleisher, D . H., Timlin, D . J., \& Reddy, V. R. (2013). Biophysical constraints to potential production capacity of potato across the US eastem seaboard region. A gronomy Journal, 106(1), 43-56. https:// doi.org/ 10.2134/ agronj2013.0277

Resop, J. P., Fleisher, D. H., Mutiibwa, D., Timlin, D . J., \& Reddy, V. R. (2016). Climate, water management, and land use: Estimating potential potato and com production in the US northeastern seaboard region. Transactions of the A SA BE , 59 (6), 1539-1553. https:/ / doi.org/ 10.13031/ trans.59.11748

Ruhf, K. Z. (2015). Regionalism: A New England recipe for a resilient food system. Journal of E nvironmental Studies and Scienoes, 5(4), 650-660. https:// doi.org/ 10.1007/ s13412-015-0324-y

Ruhf, K., \& Clancy, K. (2010). It takes a region: Exploring a regional food systems approach. N ortheast Sustainable A griaulture W orking $\mathrm{G}$ roup W ork ing Paper. Retrieved from http:/ / nesawg.org/ sites/ default/ files/ NESAWG RegionalFoodSystemFINALSept2010.pdf

Tadasse, G., Algieri, B., Kalkuhl, M., \& von Braun, J. (2016). D rivers and triggers of international food price spikes and volatility. In M. Kalkuhl, J. von Braun, \& M. Torero (Eds.), F ood Pric V olatility and Its Implications for F ood Seaurity and Policy (pp. 59-82). New Y ork: Springer.

Thompson, E., Jr., Harper, A. M., \& Kraus, S.. (2008). Think globally eat locally: San F rancisoo foodshed assessment. Washington, D.C.: American Farmland Trust. Retrieved from http:/ / 162.242.222.244/programs/ states/ca/ Feature\%20Stories/ documents/ ThinkGloballyEatLocallyFinalReport8-23-08.pdf

Wolfe, D. W., Ziska, L., Petzoldt, C., Seaman, A., Chase, L., \& Hayhoe, K. (2008). Projected change in climate thresholds in the Northeastern U.S.: Implications for crops, pests, livestock, and farmers. Mitigation and A daptation Strategies for G lobal Change, 13(5-6), 555-575. https:/ / doi.org/ 10.1007/ s11027-007-9125-2 